\title{
Empirical Study of Financial Disclosure Compliance with IFRS: Evidence from listed Romanian Companies
}

\author{
Herenia Gutierrez Ponce ${ }^{1}$, Elena Hlaciuc ${ }^{2}$, Dorel Mateș ${ }^{3}$ and Geanina Măciucă ${ }^{4}$ \\ ${ }^{1}$ Autonomous University of Madrid, Madrid, Spain \\ 2, 4"Ștefan cel Mare” University of Suceava, Suceava, Romania \\ ${ }^{3}$ West University of Timișoara, Timișoara, Romania
}

Correspondence should be addressed to: Herenia Gutierrez Ponce; herenia.gutierrez@uam.es

Received date: 9 September 2015; Accepted date: 17 December 2015; Published date: 24 May 2016

Academic Editor: Laurentiu Droj

Copyright @ 2016. Herenia Gutierrez Ponce, Elena Hlaciuc, Dorel Mateș and Geanina Măciucă. Distributed under Creative Commons CC-BY 4.0

\begin{abstract}
The international accounting regulatory bodies were faced with a major challenge: that of ensuring the comparability and transparency of the financial reporting at an international level given that many local standards make financial reporting difficult. The need for financial statements comparable internationally and at the European level attracts interest in terms of developing quality accounting standards. Internationally, the research on the compliance with IFRS, in general, and on financial reporting, in particular, continues to be important. Romania, as an integral part of the European and international economic life, is included in this project of accounting standardization. In this study, we aim to cover a set of research methods and tools in order to facilitate the scientific research. The paper will be based on the principles of quantitative research as well as on those of qualitative research. As part of quantitative research, we will use figures and the statistical analysis method. In terms of qualitative research, we aim at an intelligent description of an event. As qualitative research methods, we will research the practice of the field, using overall analysis, observation, check-list as tools. In this paper, we reviewed the main studies in the previous literature which deal with the disclosure index in the financial reports, according to the IFRS requirements. We calculated and interpreted the disclosure index in the financial statements of Romanian companies in accordance with IFRS in terms of comprehensive income. The main obstacle in making our scientific approach is the relatively small number of subjects (the small number of listed companies).
\end{abstract}

Keywords: disclosure, IFRS, comprehensive income.

Cite this Article as: Herenia Gutierrez Ponce, Elena Hlaciuc, Dorel Mateș and Geanina Măciucă (2016),"

Empirical Study of Financial Disclosure Compliance with IFRS: Evidence from listed Romanian Companies ", Journal of Accounting and Auditing: Research \& Practice, Vol. 2016 (2016), Article ID 794159,

DOI: $10.5171 / 2016.794159$ 


\section{Introduction}

While the adoption of a single set of accounting standards is beneficial, the uniform application of the International Financial Reporting Standards in all the countries where they have been adopted raises problems. "Harmony is considered crucial because it reduces the level of diversity in the financial statements for multinational enterprises. Comparability of accounting information is enhanced leading to better investment decisions and evaluation of enterprises' performance. In a world of growing international movement of funds and expanding information technology, efficient international comparison of business enterprises is essential." (Tower et., 1998).

In terms of the main types of "information disclosure", the literature of the field shows several manners of classification. Hendriksen and Breda (1992) classify disclosures as: adequate disclosure, fair disclosures, full disclosure. Disclosure is deemed adequate if it is relevant and if it satisfies the users' needs, fair if all prejudice is eliminated and if all users are treated fairly and full when the disclosure includes comprehensive information for the public.

Disclosure can be viewed in terms of the company's intentions. In this regard, it can become a non-disclosure (information that the company does not want to publish), a partial disclosure of information or a full disclosure of information. Most studies, however, remind us of the voluntary and the mandatory submission of information. Disclosure is mandatory when the companies are required to present information under a regulatory act. According to Verrechia (2001), a mandatory disclosure forces companies to present both "good" and "bad news". For financial reporting, the regulatory act is the general Conceptual framework for financial reporting issued by FASB. Disclosure is voluntary when companies are not required to present information because of a regulatory act. It is based on the manager's reasoning. Owusu Ansah defines voluntary disclosure as "any disclosure by companies not mandated by law and/or selfregulatory bodies", while the mandatory disclosure represents the minimum financial or non-financial information required by accounting standards or national regulations. Tsalavoutas (2009) believes that if the enforcement mechanisms are ineffective, the required mandatory disclosure level is similar to the voluntary one, depending on the manager's decision. The mandatory presentation is advantageous, both nationally and internationally. Other authors argue otherwise.

The unweighted, dichotomous disclosure index was proposed by T.E. Cooke in 1989 in his work entitled "Disclosure in the corporate annual reports of Swedish companies" as:

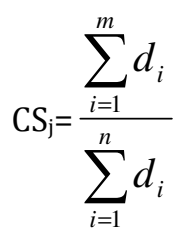

Where:

$\mathrm{CS}_{\mathrm{j}}=$ total compliance score for each company, $0 \leq \mathrm{CS}_{\mathrm{j}} \leq 1$

$\sum_{i=1}^{m} d_{i}=$ total number of items presented by the company $\mathrm{j}, \mathrm{m} \leq \mathrm{n}$

$\sum_{i=1}^{n} d_{i}=$ total number of items applicable by company $\mathrm{j}$ and which are expected to be disclosed

This index is developed from the one proposed by Buzby in 1975. Tsavaloutas (2009) believes that this disclosure index involves an important limitation: the number of disclosure items required by different standards is considerably low, in that "standards which require more items to be disclosed or, in other words, standards with more items included in the index are unintentionally and indirectly not treated 
equally with those that require fewer items to be disclosed" (Al-Shiab, 2003).

An alternative to the unweighted index method is the partial unweighted index which can be obtained by using the following formula:

$$
\mathrm{PC}_{\mathrm{j}}=\frac{\sum_{i=1} X_{i}}{R_{j}}
$$

Where:

$\mathrm{PC}_{\mathrm{j}}=$ total compliance score for each company, $0 \leq \mathrm{PC}_{\mathrm{j}} \leq 1$

$\mathrm{X}_{i}=$ the level of compliance for each standard

$\mathrm{R}_{\mathrm{j}}=$ the total number of standards applicable to each company $\mathrm{j}$,

This index was used by Street and Gray (2001) in their studies, Al-Shiab (2003, 2008) believing that "the degree of compliance for each company is measured by adding the degree of compliance for each standard and then dividing this sum by the number of standards applicable to each company. This implicitly gives equal weighting to each applicable standard and avoids the problem of unintentionally giving more weight to a standard with a larger number of items in the index" (Al-Shiab, 2003).

\section{Literature Review}

In 1999, Tower, Hancock and Taplin conducted a study on 60 companies in Australia, Hong Kong, Malaysia, Philippines, Singapore and Thailand, using as independent variables: country, company size, leverage, profitability, field of activity, number of days from the end of the reporting period and until the date on which it was presented in the Directors Report. The dependent variable is the disclosure index calculated in two ways: the first one by removing the items that are not shown and the second by including the elements not shown. The study showed that the country in which the financial statements are reported is of high importance. The disclosure index (own production), calculated using the first variant, has shown a high level of compliance with the IAS in Australia, Thailand, Malaysia, Singapore (90\%), Hong Kong and the Philippines $(89 \%$ and $88 \%)$, while the second showed a lower level, but not an alarming one. The authors consider that the level of the elements which are not disclosed is still a problem.

The same year, Street, Gray and Bryant conducted a study on a total of 49 annual reports for the year 1996 of companies from 12 different countries. The results were unsatisfactory, indicating a "significant noncompliance with IAS", only 20 of the 49 companies complying with the international accounting norms. First of all, noncompliance arises from the accounting policies adopted by the companies which contradict the IAS (Street et al., 1999). The following year, Street and Bryant return with a study applied on 82 companies from 17 different states, using as a dependent variable the disclosure index developed by Cooke in 1989 and as independent variables: company size, condition of listing, profitability, type of sector, accounting policies, the auditor's opinion on the compliance of the financial reports with the IAS, the auditor's opinion on the compliance with the auditing standards. The study results showed that the overall level of compliance was below 75\%. In 2001, Street and Gray increase the area of research to 279 companies from 32 different countries.

In 2003, Abd-Elsalam and Weetman (2003) studied the financial statements for the years 1995 and 1996 of 72 Egyptian companies, concluding that the main barriers against the application of the international accounting standards and against disclosure lie in familiarity and in linguistic issues. In 2007, the two professors returned with a study comparing the disclosure level in accounting in the annual financial reports of 1991-1992 with that of 1995-1996, stating that there is an improvement in terms of compliance with IAS. 
In Australia, Gallery, Cooper and Sweeting, on the one hand (2008), and Palmer (2008), on the other hand, conducted two studies on the impact of applying IFRS on the level of disclosure. For Gallery et al., profitability, the type of sector and the type of audit firm are associated with a high index in terms of disclosure of financial information. In Palmer's study, a high disclosure level of the 150 companies included in the study depends on the size of the audit company. Both studies assign great importance to audit and especially to the companies from the Big 4 category. In 2008, Al-Shammari used the financial reports from 1996 to 2002 of 436 companies from six countries: Bahrain, Oman, Kuwait, Saudi Arabia, Qatar and the United Arab Emirates. The highest level of compliance with IFRS was found to be in the United Arab Emirates, followed by Saudi Arabia, Kuwait, Oman, Bahrain and Qatar.

At the same time, Paananen (2008) conducted a study on a total of 314 companies regarding financial quality after the adoption of IFRS by Swedish companies in 2005. The results of his study suggest that the quality of financial reporting had not increased in the first two years after the adoption of IFRS. According to Karim and Ahmed (2005), for 188 companies from Bangladesh, the level of disclosure depends on the size of the audit firm, the size of the company, the existence of multinational firm, its profitability. Believing that the level of compliance with the international standards is as important as the standards themselves, Hodgdon et al. (2009) showed that, for the companies listed on the US stock exchanges, the compliance level is positively related to the type of auditor (Big 5+2) and to the size of the company. Through this study, the authors highlight the importance of the international auditing firms.

In Brazil, Santos, Ponte and Mapuruga (2010) conducted a study on 366 non-financial Brazilian corporations listed on the Brazilian Stock Exchange. The number of items used was 638. The authors calculated both the overall compliance index and that of each standard using as independent variables: company size, profitability, leverage, international listing, audit firm, corporate governance, type of sector. The company's size and the type of audit firm were positively associated with the dependent variable. The result of the three researchers is "partially good", contradicting other studies which show a higher disclosure index. However, they believe that after the first year of IFRS implementation, the level of transparency in terms of disclosure has increased. The use of standardised notes played an important role in it.

In 2009, Tsalavoutas, in his $\mathrm{PhD}$ thesis, presented the mandatory disclosure index, compliant with IFRS, of Greek companies. It is one of the most important works on the subject. Among the most recent studies we find that of Rajhi (2014), which analyses the annual reports of 118 French companies that are listed on NYSE Euronext, using both the dichotomous index method and the partial unweighted index method. The results of his study show that although none of the French companies listed on NYSE Euronext discloses information in full compliance with IFRS, the improvement in the level of compliance should not be overlooked.

In Romania, the studies on disclosure in the annual financial statements compliant with IFRS are relatively recent. Fekete (2009) examines the index developed by Cooke in relation to the Romanian and Hungarian companies in terms of disclosure of information about the consolidated accounts. Although for Romania the research area was quite small, the study showed that the size of the company and the type of sector "are significant and strongly associated with the level of compliance with the IFRS requirements in terms of disclosure". Also, there is no association between profitability, indebtedness, the type of auditor, foreign listing and international visibility. Disclosure in the consolidated financial statements of the companies listed on BSE was analysed by Tiron et al. (2010) as well. Like Fekete, the authors found that the preparation of consolidated financial statements is not a practice for the Romanian companies. In terms of quality, the index of disclosure under IFRS is higher for companies listed in 
category I than for those listed in category II. This is because the companies listed in category I are "bigger, more actively traded and, therefore, more visible on the market".

Gorgan (2013) performed a study on the preparation of individual financial statements in accordance with IFRS by calculating the partial unweighted compliance index. The result of his research confirms the fact that there is a correlation between the compliance index and the size of the company, the type of audit firm and international visibility.

\section{Empirical Study on Disclosure in Financial Reports Compliant with IFRS Prepared by Romanian Companies Listed on the BSE}

The objective of this research is to analyse the level of disclosure in accordance with IFRS in terms of the overall result of the individual annual financial statements drawn up by Romanian companies as a result of the adoption of IFRS for the first time. The sample for this study is made up of 58 companies listed on the Bucharest Stock Exchange in category I and II and which prepared financial statements compliant with IFRS in 2012. The disclosure index of the compliance with IFRS (in the two variants) is obtained by applying certain check-lists constructed after the model developed by Ernst \& Young for the financial statements of 2012 to the following international financial reporting standards: IFRS 1- First-time adoption of IFRS, IAS 1 Presentation of financial statements, IAS 2 Inventories, IAS 12 - Income taxes, IAS 16 Property, plant and equipment, IAS 18 Revenue, IAS 29 - Financial reporting in hyperinflationary economies, IAS 36 Impairment of assets, IAS 38 - Intangible assets, IAS 40 - Investment property. In choosing these standards, we took into account the impact of the adoption of IFRS on the overall result. By applying the recognition criteria under IFRS, the Romanian companies listed on the BSE needed to acknowledge a number of adjustments.

\section{The Definition of the Variables Researched}

In this study, the dependent variable is the index of disclosure in accordance with IFRS, calculated as follows: partial unweighted index method (PC) and unweighted dichotomous index method (CS).

H1: there is a correlation between disclosure index (CS) and disclosure index (PC)

The independent variables researched are:

\section{The Listing Category}

On the Bucharest Stock Exchange, there are three listing categories: I, II and III. Beside these, we have the unlisted companies. In our study, we have removed the companies from category III and those which are unlisted.

$\mathrm{H} 2$ : there is a difference between listing category I and listing category II in terms of the disclosure index

\section{Company Size}

This variable is one of the most used in studies on the disclosure index of financial information, whether it is in relation with the index calculation at corporate level or in terms of compliance with IFRS. Most studies show that company size is directly associated with a high disclosure index. One explanation is that large companies undertake more activities and have a greater impact on society. Another explanation would be that large companies are also subjected to more detailed checks which imply a higher pressure in terms of disclosure (Haniffa, Cooke, 2005).

H3: there is a link between the disclosure index and the size of the company

\section{Profitability}

As an independent variable of company size, profitability (ROE) is one of the most used variables. Previous studies have shown that there is no dependency between profitability and disclosure, while other studies did not 
include this variable. "A possible explanation for a positive association between the disclosure index and profitability is that management has the freedom and flexibility to undertake and reveal more extensive social responsibility programmes to shareholders. Profit-able companies disclose social information to demonstrate their contribution to society" (Haniffa, Cooke, 2005).

H4: there is a link between the disclosure index and profitability

\section{Type of Auditor}

For Street and Gray (2002), the type of auditor (if we are dealing with an international audit firm) is positively associated with the disclosure index compliant with IFRS. Also, Palmer (2008) notices that the level of compliance with the requirements of IFRS is higher when the company is audited by international audit firms than when it is audited by smaller firms.

H5: there will be a difference in average concerning the disclosure index between the Big 4 auditor type and the type of internal auditor.

\section{Type of Sector}

In the literature on the topic, there are many studies which have used the type of sector as an independent variable. Some of them have shown a link between the information level and the type of sector (Cooke, 1992, Raffournier, 1995). In contrast, other studies have found no difference between them (Watson et al. 2002).

H6: the disclosure index will vary depending on the type of sector

\section{Shareholding Structure}

In our study, we will consider the shareholding structure as an independent variable: autochthonous, foreign, mixed.
H7: the independent variable, the shareholding structure, influences the value of the disclosure index

\section{Stock Market Age}

Being listed on the stock market for a long period of time can influence the quality of financial reporting. We forward the following hypothesis:

H8: there is a link between the disclosure index and the stock market age

\section{Experience in the Preparation of Consolidated Financial Statements}

The experience in the preparation of consolidated financial statements leaves its mark on the financial reporting of the companies listed on BSE.

H9: the disclosure index will vary according to the experience in the preparation of consolidated financial statements

\section{Auditor's Opinion}

H10: the disclosure index will vary depending on the auditor's opinion

\section{Analysis and Interpretation of Results}

In order to test the hypotheses, we used the statistical program SPSS 21.

$\mathrm{H} 1$ : there is a correlation between disclosure index (CS) and disclosure index (PC)

The research activity implied the calculation of the disclosure index both by using the unweighted dichotomous index method (CS) and the partial unweighted index method (PC). To check whether there is a link between the two indices, we applied the Pearson correlation analysis (Table no. 1). The results indicated that there was a significant positive correlation between the two variables $[\mathrm{r}=.921, \mathrm{~N}=58, \mathrm{p}=0.000$ ] (see table no.1). 
Table 1: Pearson correlation analysis to verify hypothesis H1

\begin{tabular}{|l|c|c|c|}
\hline \multicolumn{2}{|c|}{} & Disclosure index (CS) & $\begin{array}{c}\text { Disclosure } \\
\text { index (PC) }\end{array}$ \\
\hline \multirow{3}{*}{$\begin{array}{l}\text { Disclosure } \\
\text { index (CS) }\end{array}$} & Pearson Correlation & 1 &, $921^{* *}$ \\
\cline { 2 - 4 } & Sig. (2-tailed) & &, 000 \\
\cline { 2 - 4 } & $\mathrm{N}$ & 58 & 58 \\
\hline \multirow{3}{*}{$\begin{array}{l}\text { Disclosure } \\
\text { index (PC) }\end{array}$} & Pearson Correlation &, $921^{* *}$ & 1 \\
\cline { 2 - 4 } & Sig. (2-tailed) &, 000 & 58 \\
\cline { 2 - 4 } & $\mathrm{N}$ & 58 & \\
\hline \multirow{2}{*}{$* *$. Correlation is significant at the 0.01 level (2-tailed). } & \multicolumn{2}{|c}{} \\
\hline
\end{tabular}

Source: own processing with SPSS 21

In other words, the results indicated that there is a positive correlation between the unweighted dichotomous index (CS) and the partial unweighted index.

$\mathrm{H} 2$ : there is a difference between listing category I and listing category II in terms of the disclosure index

To check if there is a difference between the averages of the two listing categories regarding the disclosure index, we have applied the Independent-Samples T Test. The results have shown that the average of the disclosure index (CS) for listing category I $(M=0,86, \quad S D=0,036)$ does not differ statistically from the average of the disclosure index (CS) for listing category II $(M=0,83, \quad S D=0,075)$. Furthermore, the results have also shown that the average of the disclosure index (CS) for listing category I $(M=0,79, \quad S D=0,041)$ does not differ statistically from the average of the disclosure index (CS) for listing category II $(\mathrm{M}=0,78, \mathrm{SD}=0,084)$.

Table 2: Group statistic to verify the hypothesis $\mathrm{H} 2$

\begin{tabular}{|l|c|c|c|c|c|}
\hline & Listing category & $\mathrm{N}$ & Mean & Std. Deviation & Std. Error Mean \\
\hline $\begin{array}{l}\text { Disclosure } \\
\text { index (CS) }\end{array}$ & Listing category I & 12 &, 8558 &, 03554 &, 01026 \\
\cline { 2 - 6 } & Listing category II & 46 &, 8348 &, 07506 &, 01107 \\
\hline $\begin{array}{l}\text { Disclosure } \\
\text { index (PC) }\end{array}$ & Listing category I & 12 &, 7883 &, 04064 &, 01173 \\
\cline { 2 - 6 } & Listing category II & 46 &, 7852 &, 08498 &, 01253 \\
\hline
\end{tabular}

Source: own processing with SPSS 21

H3: there is a link between the disclosure index and the size of the company

In order to check the hypothesis, we applied Pearson correlation analysis. The results indicated that there is a statistically significant positive correlation with a significance threshold of less than 0.10 (borderline significance) between:

- The disclosure index (PC) and the company size (turnover) ( $r=0,25, \mathrm{p}=0,059, \mathrm{~N}=58)$;

- The disclosure index (PC) and the company size (total assets) ( $r=0,232, p=0,080, N=58)$; 
- The disclosure index (CS) and the company size (turnover) ( $\mathrm{r}=0,22, \mathrm{p}=0,097, \mathrm{~N}=58)$.

The effect size in all these cases is small, $r<0,30$. As far as the Pearson correlation is concerned, statistically speaking, we did not find a significant correlation at a significance threshold of 0.10 . According to statisticians, the significance threshold can be low, being considered borderline significance. In this case, the hypothesis is partially confirmed.

Table 3: Independent Samples Test to verify hypothesis H3

\begin{tabular}{|c|c|c|c|c|c|c|c|c|c|c|}
\hline \multicolumn{11}{|c|}{ Independent Samples Test } \\
\hline & & $\begin{array}{l}\text { Levene } \\
\text { for Equ } \\
\text { Varian }\end{array}$ & $\begin{array}{l}\text { Test } \\
\text { lity of } \\
\text { s }\end{array}$ & \multicolumn{7}{|c|}{ t-test for Equality of Means } \\
\hline & & \multirow[t]{2}{*}{$\mathrm{F}$} & \multirow[t]{2}{*}{ Sig. } & \multirow[t]{2}{*}{$\mathrm{t}$} & \multirow[t]{2}{*}{ df } & \multirow[t]{2}{*}{$\begin{array}{c}\text { Sig. } \\
\text { (2-taile) }\end{array}$} & \multirow[t]{2}{*}{$\begin{array}{c}\text { Mean } \\
\text { Difference }\end{array}$} & \multirow[t]{2}{*}{$\begin{array}{l}\text { Std. Error } \\
\text { Difference }\end{array}$} & \multicolumn{2}{|c|}{$\begin{array}{l}\text { 95\% Confidence } \\
\text { Interval of the } \\
\text { Difference }\end{array}$} \\
\hline & & & & & & & & & Lower & Upper \\
\hline \multirow{2}{*}{$\begin{array}{l}\text { Disclosure } \\
\text { index (CS) }\end{array}$} & $\begin{array}{l}\text { Equal } \\
\text { variances } \\
\text { assumed }\end{array}$ & 2,573 & ,114 & 940 & 56 & ,351 & 02105 & ,02240 &,- 02382 & ,06592 \\
\hline & $\begin{array}{l}\text { Equal } \\
\text { variances } \\
\text { not } \\
\text { assumed }\end{array}$ & & & 1,395 & 38,694 & ,171 & ,02105 & ,01509 &,- 00948 & ,05158 \\
\hline \multirow[b]{2}{*}{$\begin{array}{l}\text { Disclosure } \\
\text { index (PC) }\end{array}$} & $\begin{array}{l}\text { Equal } \\
\text { variances } \\
\text { assumed }\end{array}$ & 3,893 & ,053 & ,123 & 56 & ,903 & 00312 & 02537 &,- 04771 & ,05394 \\
\hline & $\begin{array}{l}\text { Equal } \\
\text { variances } \\
\text { not } \\
\text { assumed }\end{array}$ & & & 182 & 38,243 & ,857 & ,00312 & ,01716 &,- 03162 & ,03786 \\
\hline
\end{tabular}

Source: own processing with SPSS 21

Table 4: Pearson correlation to verify hypothesis $\mathrm{H3}$

\begin{tabular}{|l|l|l|l|c|}
\hline \multicolumn{2}{|c|}{} & $\begin{array}{l}\text { lompany } \\
\text { size } \\
\text { (turnover) }\end{array}$ & $\begin{array}{l}\text { Stock market } \\
\text { age }\end{array}$ & $\begin{array}{l}\text { Company size } \\
\text { (total assets) }\end{array}$ \\
\hline \multirow{3}{*}{$\begin{array}{l}\text { Disclosure index } \\
\text { (CS) }\end{array}$} & $\begin{array}{l}\text { Pearson } \\
\text { Correlation }\end{array}$ &, 220 &,- 257 &, 215 \\
\cline { 2 - 5 } & Sig. (2-tailed) &, 097 &, 051 &, 104 \\
\cline { 2 - 5 } & $\mathrm{N}$ & 58 & 58 & 58 \\
\hline \multirow{4}{*}{$\begin{array}{l}\text { Disclosure index } \\
\text { (PC) }\end{array}$} & $\begin{array}{l}\text { Pearson } \\
\text { Correlation }\end{array}$ &, 250 &,- 232 &, 232 \\
\cline { 2 - 5 } & Sig. (2-tailed) &, 059 &, 079 &, 080 \\
\cline { 2 - 6 } & $\mathrm{N}$ & 58 & 58 & 58 \\
\cline { 2 - 5 } & Sig. (2-tailed) &, 599 &, 671 & 586 \\
\cline { 2 - 5 } & $\mathrm{N}$ & 58 & 58 & 58 \\
\hline
\end{tabular}

Source: own processing with SPSS 21

H4: there is a link between the disclosure index and profitability

By applying the Pearson correlation, this assumption was refuted because there is no statistically significant positive correlation between the disclosure index and profitability. 
H5: there will be a difference in average concerning the disclosure index between the Big 4 auditor type and the type of internal auditor.

To check this hypothesis, we applied the Independent-Samples $\mathrm{T}$ Test. The results indicated that there is a significant difference between the Big 4 auditor type $(M=0,81$,
$\mathrm{SD}=0,06, \mathrm{~N}=18)$ and the type of internal auditor $(M=0,77, S D=0,07, N=40), p=0,034$ (see table no.5). We can say that the auditor type has an influence on the disclosure index (PC). As far as the disclosure index (CS) is concerned, we found no significant difference in average concerning between Big 4 auditor type and the type of internal auditor (see table no. 6).

Table 5: Group statistic to verify hypothesis H5

\begin{tabular}{|c|l|c|c|c|c|}
\hline \multicolumn{2}{|c|}{ Group Statistics } \\
\hline & Type of auditor & $\mathrm{N}$ & Mean & $\begin{array}{c}\text { Std. } \\
\text { Deviation }\end{array}$ & Std. Error Mean \\
\hline $\begin{array}{c}\text { Disclosure index } \\
(\text { CS) }\end{array}$ & Big4 auditor & 18 &, 8594 &, 04696 &, 01107 \\
\cline { 2 - 6 } & internal auditor & 40 &, 8300 &, 07568 &, 01197 \\
\hline $\begin{array}{c}\text { Disclosure index } \\
\text { (PC) }\end{array}$ & Big4 auditor & 18 &, 8178 &, 06504 &, 01533 \\
\cline { 2 - 6 } & $\begin{array}{l}\text { internal } \\
\text { auditor }\end{array}$ & 40 &, 7715 &, 07921 &, 01252 \\
\hline
\end{tabular}

Source: own processing with SPSS 21

Table 6: Independent Samples Test to verify hypothesis H5

\begin{tabular}{|c|c|c|c|c|c|c|c|c|c|c|}
\hline \multicolumn{11}{|c|}{ Independent Samples Test } \\
\hline & & \multicolumn{2}{|c|}{$\begin{array}{l}\text { Levene's Test } \\
\text { for Equality } \\
\text { of Variances }\end{array}$} & \multicolumn{7}{|c|}{ t-test for Equality of Means } \\
\hline & & \multirow[t]{2}{*}{$\mathrm{F}$} & \multirow{2}{*}{ Sig. } & \multirow[t]{2}{*}{$\mathrm{t}$} & \multirow{2}{*}{$\mathrm{df}$} & \multirow{2}{*}{$\begin{array}{c}\text { Sig. } \\
\text { (2-tailed) }\end{array}$} & \multirow{2}{*}{$\begin{array}{c}\text { Mean } \\
\text { Difference }\end{array}$} & \multirow{2}{*}{$\begin{array}{l}\text { Std. Error } \\
\text { Difference }\end{array}$} & \multicolumn{2}{|c|}{$\begin{array}{l}95 \% \text { Confidence } \\
\text { Interval of the } \\
\text { Difference } \\
\end{array}$} \\
\hline & & & & & & & & & Lower & Upper \\
\hline \multirow{2}{*}{$\begin{array}{l}\text { Disclo } \\
\text { sure } \\
\text { index } \\
(\mathrm{CS})\end{array}$} & $\begin{array}{l}\text { Equal } \\
\text { variances } \\
\text { assumed }\end{array}$ & 1,009 & ,320 & 1,520 & 56 & 134 & 02944 & 01937 &,- 00936 & ,06825 \\
\hline & $\begin{array}{l}\text { Equal } \\
\text { variances } \\
\text { not } \\
\text { assumed }\end{array}$ & & & 1,806 & 50,117 & 077 & 02944 & 01630 &,- 00330 & ,06218 \\
\hline \multirow{2}{*}{$\begin{array}{l}\text { Disclo } \\
\text { sure } \\
\text { index } \\
(\mathrm{PC})\end{array}$} & $\begin{array}{l}\text { Equal } \\
\text { variances } \\
\text { assumed }\end{array}$ & 047 & ,829 & 2,168 & 56 & ,034 & 04628 & 02134 & ,00353 & 08903 \\
\hline & $\begin{array}{l}\text { Equal } \\
\text { variances } \\
\text { not } \\
\text { assumed }\end{array}$ & & & 2,338 & 39,582 & 025 & 04628 & 01980 & ,00626 & 08630 \\
\hline
\end{tabular}

Source: own processing with SPSS 21 
H6: the disclosure index will vary depending on the type of sector

By applying the Pearson correlation, this assumption was refuted because there is no statistically significant positive correlation between the disclosure index and the type of sector.

H7: the independent variable, the shareholding structure, influences the value of the disclosure index

We took into account the shareholding structure and two dependent variables: disclosure index (CS) and disclosure index (PC). The independent variable is shown on the following levels: foreign, mixed, native. We applied the One-way ANOVA method. The results indicated that there is a difference in average between the local and joint shareholding types regarding the disclosure index (CS) (table no. 8). Therefore, there is a significant difference between the structure of the local shareholding and the joint one (Mdif=-0,05686, SE=0,02526, p=0,028) (table no.9). In other cases, we found no significant differences between averages.

Table 7 : Frequency variable -shareholding structure

\begin{tabular}{|c|l|c|c|c|c|}
\hline \multicolumn{6}{|c|}{ Shareholding structure } \\
\hline \multirow{3}{*}{} & native & 35 & 60,3 & 60,3 & 60,3 \\
\cline { 2 - 6 } Valid & foreign & 11 & 19,0 & 19,0 & 79,3 \\
\cline { 2 - 6 } & mixed & 12 & 20,7 & 20,7 & 100,0 \\
\cline { 2 - 6 } & Total & 58 & 100,0 & 100,0 & \\
\hline
\end{tabular}

Source: own processing with SPSS 21

Table 8: ANOVA-to test hypothesis $\mathrm{H} 7$

\begin{tabular}{|c|c|c|c|c|c|c|}
\hline \multicolumn{7}{|c|}{ ANOVA } \\
\hline & & $\begin{array}{l}\text { Sum of } \\
\text { Squares }\end{array}$ & $\mathrm{df}$ & $\begin{array}{l}\text { Mean } \\
\text { Square }\end{array}$ & $\mathrm{F}$ & Sig. \\
\hline \multirow{3}{*}{$\begin{array}{l}\text { Disclosure } \\
\text { index (CS) }\end{array}$} & $\begin{array}{l}\text { Between } \\
\text { Groups }\end{array}$ & ,004 & 2 & 002 & 399 & 673 \\
\hline & $\begin{array}{l}\text { Within } \\
\text { Groups }\end{array}$ & 268 & 55 & 005 & & \\
\hline & Total & 272 & 57 & & & \\
\hline \multirow{3}{*}{$\begin{array}{l}\text { Disclosure } \\
\text { index (PC) }\end{array}$} & $\begin{array}{l}\text { Between } \\
\text { Groups }\end{array}$ & 030 & 2 & 015 & 2,604 & 083 \\
\hline & $\begin{array}{l}\text { Within } \\
\text { Groups }\end{array}$ & 314 & 55 & 006 & & \\
\hline & Total & ,343 & 57 & & & \\
\hline
\end{tabular}

Source: own processing with SPSS 21 
Table 9: Multiple Comparisons to test hypothesis $\mathrm{H7}$

\begin{tabular}{|c|c|c|c|c|c|c|c|}
\hline \multicolumn{8}{|c|}{ Multiple Comparisons } \\
\hline \multicolumn{8}{|c|}{ LSD } \\
\hline \multirow{2}{*}{$\begin{array}{l}\text { Dependent } \\
\text { Variable }\end{array}$} & \multirow{2}{*}{$\begin{array}{l}\text { (I)Sharehol } \\
\text { ding } \\
\text { structure }\end{array}$} & \multirow{2}{*}{$\begin{array}{l}\text { (J) } \\
\text { Sharehol } \\
\text { ding } \\
\text { structure }\end{array}$} & \multirow{2}{*}{$\begin{array}{l}\text { Mean } \\
\text { Difference } \\
(\mathrm{I}-\mathrm{J})\end{array}$} & \multirow{2}{*}{$\begin{array}{l}\text { Std. } \\
\text { Error }\end{array}$} & \multirow{2}{*}{ Sig. } & \multicolumn{2}{|c|}{$\begin{array}{l}95 \% \text { Confidence } \\
\text { Interval }\end{array}$} \\
\hline & & & & & & $\begin{array}{l}\text { Lower } \\
\text { Bound }\end{array}$ & $\begin{array}{l}\text { Upper } \\
\text { Bound }\end{array}$ \\
\hline \multirow{6}{*}{$\begin{array}{l}\text { Disclosure } \\
\text { index (CS) }\end{array}$} & \multirow{2}{*}{ native } & foreign & ,00299 & 02412 & ,902 &,- 0453 & 0513 \\
\hline & & mixed &,- 01929 & 02334 & 412 &,- 0661 & 0275 \\
\hline & \multirow{2}{*}{ foreign } & native &,- 00299 & 02412 & 902 &,- 0513 & 0453 \\
\hline & & mixed &,- 02227 & 02913 & 448 &,- 0806 & 0361 \\
\hline & \multirow{2}{*}{ mixed } & native & 01929 & 02334 & ,412 &,- 0275 & ,0661 \\
\hline & & foreign & 02227 & 02913 & 448 &,- 0361 & 0806 \\
\hline \multirow{6}{*}{$\begin{array}{l}\text { Disclosure } \\
\text { index (PC) }\end{array}$} & \multirow{2}{*}{ native } & foreign &,- 00504 & 02610 & 848 &,- 0573 & 0473 \\
\hline & & mixed &,$- 05686^{*}$ & 02526 & 028 &,- 1075 &,- 0062 \\
\hline & \multirow{2}{*}{ foreign } & native & ,00504 & ,02610 & 848 &,- 0473 & 0573 \\
\hline & & mixed &,- 05182 & 03152 & 106 &,- 1150 & ,0113 \\
\hline & \multirow{2}{*}{ mixed } & native &, $05686^{*}$ & ,02526 & 028 & 0062 & 1075 \\
\hline & & foreign & ,05182 & ,03152 & 106 &,- 0113 & 1150 \\
\hline
\end{tabular}

Source: own processing with SPSS 21

H8: there is a link between the disclosure index and the stock market age

By applying the Pearson correlation, this assumption was refuted because there is no statistically significant positive correlation between the disclosure index and the stock market age.

H9: the disclosure index will vary according to the experience in the preparation of consolidated financial statements
To verify this hypothesis, we applied the Independent-Samples $\mathrm{T}$ Test. The results indicated that both the disclosure indicator (CS) and the disclosure indicator (PC) do not vary statistically depending on the experience in the preparation of consolidated financial statements: for the disclosure index (CS), $\mathrm{p}=0,678$, and for the disclosure index (PC), $\mathrm{p}=0,947$. (Table no.11) 
Table 10 : Group Statistics to verify hypothesis H9

\begin{tabular}{|c|c|c|c|c|c|}
\hline \multicolumn{6}{|c|}{ Group Statistics } \\
\hline & $\begin{array}{lrr}\begin{array}{l}\text { Experience } \\
\text { preparation }\end{array} & \text { the } \\
\text { consolidated } & \text { of } \\
\text { statements } & & \end{array}$ & $\mathrm{N}$ & Mean & $\begin{array}{c}\text { Std. } \\
\text { Deviation }\end{array}$ & $\begin{array}{l}\text { Std. } \\
\text { Error } \\
\text { Mean }\end{array}$ \\
\hline \multirow{2}{*}{ Disclosure index (CS) } & yes & 19 & ,8337 & 08977 & ,02059 \\
\hline & no & 39 & ,8418 & 05753 & ,00921 \\
\hline \multirow{2}{*}{ Disclosure index (PC) } & yes & 19 & 7868 & 09569 & 02195 \\
\hline & no & 39 & ,7854 & 06851, & 01097, \\
\hline
\end{tabular}

Source: own processing with SPSS 21

Table 11: Independent Samples Test to verify hipothesis H9

\begin{tabular}{|c|c|c|c|c|c|c|c|c|c|c|}
\hline \multicolumn{11}{|c|}{ Independent Samples Test } \\
\hline & & \multicolumn{2}{|c|}{$\begin{array}{l}\text { Levene's } \\
\text { Test for } \\
\text { Equality of } \\
\text { Variances }\end{array}$} & \multicolumn{7}{|c|}{ t-test for Equality of Means } \\
\hline & & \multirow[t]{2}{*}{$\mathrm{F}$} & \multirow[t]{2}{*}{ Sig. } & \multirow[t]{2}{*}{$\mathrm{t}$} & \multirow[t]{2}{*}{ df } & \multirow{2}{*}{$\begin{array}{l}\text { Sig. } \\
\text { (2-tailed) }\end{array}$} & \multirow{2}{*}{$\begin{array}{l}\text { Mean } \\
\text { Difference }\end{array}$} & \multirow{2}{*}{$\begin{array}{l}\text { Std. Error } \\
\text { Difference }\end{array}$} & \multicolumn{2}{|c|}{$\begin{array}{l}\text { 95\% Confidence } \\
\text { Interval of the } \\
\text { Difference }\end{array}$} \\
\hline & & & & & & & & & Lower & Upper \\
\hline \multirow[t]{2}{*}{$\begin{array}{l}\text { Disclosure } \\
\text { index (CS) }\end{array}$} & $\begin{array}{l}\text { Equal } \\
\text { variances } \\
\text { assumed }\end{array}$ & ,818 & ,370 &,- 417 & 56 & 678 &,- 00811 & ,01946 &,- 04709 & ,03086 \\
\hline & $\begin{array}{l}\text { Equal } \\
\text { variances } \\
\text { not } \\
\text { assumed }\end{array}$ & & &,- 360 & 25,442 & ,722 &,- 00811 & ,02256 &,- 05453 & 03831 \\
\hline \multirow[t]{2}{*}{$\begin{array}{l}\text { Disclosure } \\
\text { index (PC) }\end{array}$} & $\begin{array}{l}\text { Equal } \\
\text { variances } \\
\text { assumed }\end{array}$ &, 509 & ,479 & ,067 & 56 & ,947 & 00146 & ,02190 &,- 04242 & 04533 \\
\hline & $\begin{array}{l}\text { Equal } \\
\text { variances } \\
\text { not } \\
\text { assumed }\end{array}$ & & & 059 & 27,307 & ,953 & 00146 &, 02454 &,- 04887 & ,05178 \\
\hline
\end{tabular}

Source: own processing with SPSS 21

H10: the disclosure index will vary depending on the auditor's opinion

To verify this hypothesis, we applied the Independent-Samples $\mathrm{T}$ Test. The results indicated that both the disclosure indicator
(CS) and the disclosure indicator (PC) do not vary statistically depending on the auditor's opinion: for the disclosure index (CS), $p=0,241$, and for the disclosure index (PC), $\mathrm{p}=0,212$. (Table no.13) 
Table 12 : Group Statistics to verify hypothesis H10

\begin{tabular}{|c|c|c|c|c|c|}
\hline \multicolumn{7}{|c|}{ Group Statistics } \\
\hline & Auditors' opinion & $\mathrm{N}$ & Mean & Std. Deviation & $\begin{array}{c}\text { Std. Error } \\
\text { Mean }\end{array}$ \\
\hline \multirow{2}{*}{ Disclosure index (CS) } & without reserves & 37 &, 8311 &, 07770 &, 01277 \\
\cline { 2 - 6 } & with reserves & 21 &, 8533 &, 04882 &, 01065 \\
\hline \multirow{2}{*}{ Disclosure index (PC) } & without reserves & 37 &, 7762 &, 08460 &, 01391 \\
\cline { 2 - 6 } & with reserves & 21 &, 8029 &, 06166 &, 01345 \\
\hline
\end{tabular}

Source: own processing with SPSS 21

Table 13: Independent Samples Test to verify hipothesis H10

\begin{tabular}{|c|c|c|c|c|c|c|c|c|c|c|}
\hline \multicolumn{11}{|c|}{ Independent Samples Test } \\
\hline & & \multicolumn{2}{|c|}{$\begin{array}{l}\text { Levene's Test } \\
\text { for Equality } \\
\text { of Variances }\end{array}$} & \multicolumn{7}{|c|}{ t-test for Equality of Means } \\
\hline & & \multirow{2}{*}{$\mathrm{F}$} & \multirow{2}{*}{ Sig. } & \multirow{2}{*}{$\mathrm{t}$} & \multirow{2}{*}{$\mathrm{df}$} & \multirow{2}{*}{$\begin{array}{l}\text { Sig. (2- } \\
\text { tailed) }\end{array}$} & \multirow{2}{*}{$\begin{array}{c}\text { Mean } \\
\text { Difference }\end{array}$} & \multirow{2}{*}{$\begin{array}{l}\text { Std. Error } \\
\text { Difference }\end{array}$} & \multicolumn{2}{|c|}{$\begin{array}{l}\text { 95\% Confidence } \\
\text { Interval of the } \\
\text { Difference }\end{array}$} \\
\hline & & & & & & & & & Lower & Upper \\
\hline \multirow{2}{*}{$\begin{array}{l}\text { Disclosure } \\
\text { index (CS) }\end{array}$} & $\begin{array}{c}\text { Equal } \\
\text { variances } \\
\text { assumed }\end{array}$ & 1,180 & ,282 & $-1,184$ & 56 & ,241 &,- 02225 & 01880 &,- 05990 & 01540 \\
\hline & $\begin{array}{c}\text { Equal } \\
\text { variances } \\
\text { not } \\
\text { assumed }\end{array}$ & & & $-1,338$ & 55,322 & ,186 &,- 02225 & 01663 &,- 05558 & 01108 \\
\hline \multirow{2}{*}{$\begin{array}{l}\text { Disclosure } \\
\text { index (PC) }\end{array}$} & $\begin{array}{c}\text { Equal } \\
\text { variances } \\
\text { assumed }\end{array}$ & ,781 & ,381 & $-1,263$ & 56 & ,212 &,- 02664 & 02109 &,- 06889 & 01561 \\
\hline & $\begin{array}{c}\text { Equal } \\
\text { variances } \\
\text { not } \\
\text { assumed }\end{array}$ & & & $-1,377$ & 52,364 & 174 &,- 02664 & 01935 &,- 06547 & 01218 \\
\hline
\end{tabular}

Source: own processing with SPSS 21

\section{Conclusion}

Firstly, our study shows the small number of subjects under investigation as being the main limitation. We tried to compensate for this limitation by using both calculation methods of the disclosure index while taking into account a larger number of international accounting standards. Our research showed that the disclosure index does not present any significant differences which could influence the research results. Thus, we notice that the disclosure index (obtained by using both the PC and CS methods) shows a satisfactory level of compliance with IFRS, most companies having an index between 0.7 and 0.90 .

The results of our study have shown that the disclosure index regarding the level of compliance with IFRS is positively influenced by the type of auditor and the shareholder structure. The paradigm is maintained that an international firm can influence the level of compliance with IFRS in financial statements but, what we have noticed during 
our research is that the small, local audit firms have become more demanding.

Instead, the listing category, profitability, the stock market age and the experience in the preparation of consolidated financial statements do not influence the disclosure index compliant with IFRS. The company size has partial influence.

We believe that this study represents a challenge for future studies, the compliance with the IFRS requirements continuing to be a current issue not only for Romania but for other countries as well. Since the application of IFRS will extend to state-owned entities, our future research will focus on the compliance of their financial statements.

\section{References}

1. Abd-Elsalam, O.H. and Weetman, P. (2003) 'Introducing International Accounting Standards to an emerging capital market: relative familiarity and language effect in Egypt', Journal of International Accounting, Auditing \& Taxation, 12, 63-84.

2. Al-Shammari, B., Brown, P., and Tarca, A. (2008) 'An investigation of compliance with international accounting standards by listed companies in the Gulf Co-Operation Council member states', The International Journal of Accounting, 43 (4), 425-447.

3. Al-Shiab (2003) 'Financial consequences of IAS adoption: Te case of Jordan, University of New Castle Upon-Tyne.

4. Al-Shiab, M. (2008) 'The effectiveness of International Financial Reporting Standards adoption on cost of equity capital: A vector error correction model', International Journal of Business, 13(3), 271-298.

5. Fekete, S. (2009) Cercetare conceptuală și empirică privind raportările financiare din România și Ungaria. Convergență și conformitate cu IFRS, Casa Cărții de Știință, Cluj-Napoca.

6. Fekete, S. (2008) 'Raportările financiare în contextul asimetriei informaționale, guvernanței corporative și al globalizării. Implicații pentru România', Accounting and Management Information Systems, 23, 6-19.

7. Gallery, G., Cooper, E. and Sweeting, J. (2008) 'Corporate Disclosure Quality: Lessons from Australian Companies on the impact of Adopting International Financial Reporting Standards', Australian Accounting Review, 18 (3), 257-273.

8. Gorgan C. (2013) Convergența contabilă internațională. Implicații asupra raportării financiare, Editura ASE, București,

9. Gutierrez Ponce, H. and Navallas Labat B., (2008) 'Divulagion voluntaria de informacion:estado de la cuestion', 195, 6475, www.partidadoble.es.

10. Haniffa, C. and Cooke, T.E. (2005) 'The impact of culture and governance on corporate social reporting', Journal of accounting and Public Policy, 24 (5), 391-430.

11. Hendriksen, E. and Breda M. F. (1992) Accounting Theory, Fifth Edition, Irwin, Inc., Boston.

12. Hodgdon, C., Tondkar, R.H., Adhikari, A. A. and Harless, D.W. (2009) 'Compliance with International Financial Reporting Standards and auditor choice: New evidence on the importance of the statutory audit', The International Journal of Accounting, 44, 3355.

13. Hossain, M. and Hammami H. (2009) 'Voluntary disclosure in the annual reports of an emerging country: the case of Qatar', Advances in Accounting, 25 (2), 255-265.

14. Karim, A.K.M.W. and Ahmed, J.U. (2005) 'Determinants of IAS disclosure compliance in emerging economies: Evidence from exchange-listed companies in Bangladesh', Working paper series nr. 21.

15. Paananen, M. (2008) 'The IFRS adoption's Effect on Accounting Quality in Sweden', Working Paper, University of Hertfordshire. 
16. Palmer, P.D. (2008) 'Disclosure of the impacts of adopting Australian equivalents of International Financial Reporting Standards', Accounting and Finance, 48 (5), 847-870.

17. Rajhi, M. (2014) 'International Financial Reporting Standards and Level of Compliance with Mandatory Disclosure Requirements', International Journal of Multidisciplinarity Sciences and Engineering, 5 (5), 1-6.

18. Santos, E.S., Ponte, V.M. and Mapurunga P.V. (2014) 'Mandatory IFRS Adoption In Brazil (2010): Index of Compliance with Disclosure Requirements and Explanatory Factors of Firms Reporting', Working Paper, Revista Contabilidade \& Finanças, 25 (65), online version

http://www.scielo.br/scielo.php?pid=S1519

70772014000200161\&script=sci_arttext\&tln $\mathrm{g}=\mathrm{en}$.

19. Street, D.L., Gray, S.J. and Bryant S.M. (1999) 'Acceptance and observance of International Accounting Standards: An empirical study of companies claiming to comply with IASs', The International Journal of Accounting, 34 (1), 11-48.
20. Street, D., and Gray, S. (2001) 'Observance of International Accounting Standards: Factors explaining noncompliance', Association of Chartered Certified Accountants (ACCA) Research Report, 74, London, UK.

21. Tower, G., Hancock, P. and Taplin, R.H. (1998), A regional study of listed companies compliance with international accounting standards, Accounting Forum, 23 (3), 293305.

22. Tsalavoutas, I. (2009) The adoption of IFRS by Greek listed companies:financial statement effects, level of compliance and value relevance, University of Edinburgh.

23. Verrechia, R.E. (2001) 'Essays on disclosure', Journal of Accounting and Economics, 32 (1-3), 97-180.

24. Vlăsceanu, L. (1986), Metodologia cercetării sociale, Editura Științifică și Enciclopedică, București.

25. Watson, A., Shrives, P. and Marston, C. 'Voluntary disclosure of accounting ratios in the UK', British Accounting Review, 34, (4), 289- 313. 